\title{
Groundwater Quality Mapping of an Open Municipal Solid waste Landfill Site
}

\author{
Thayalnayaki D, Jayanthi R
}

\begin{abstract}
The common practice of Municipal solid waste disposal method in developing countries is an unlined landfill dumping site. Due to this the natural resources land, water and air get polluted and also severely affected by the public living around the dumping yard. In this study, Srinivasapuram dumpsite in Thanjavur City Municipal Corporation area, India has been selected to investigate the quality of groundwater. Groundwater samples collected from 25 locations were tested as per standards for physical, chemical characteristics. The classical contour mapping method has been used to detect information from the recorded ground water quality data. Surfer 6.0 software has been used to convert the spatial data into equivalent contour map. Graphical method has been used to decide the area enclosed by each contour line. The water quality standards recommended by BIS and WHO were used to classify the critical regions based on the ground water contamination level. The water quality parameters such as $\mathrm{pH}$ value, Electrical conductivity, Total dissolved solids (TDS), Total Hardness (TH), Iron and Fluoride were considered for this analysis and other parameters were not included. All the collected groundwater samples the $\mathrm{pH}$ values are within the permissible limit of 6.5-8.5. The Electrical Conductivity vales range between $0.5 \mathrm{mho} / \mathrm{cm}$ and $5.7 \mathrm{mho} / \mathrm{cm}$. The TDS values ranges between 200 and $3024 \mathrm{mg} / \mathrm{l}$. The concentration of TDS is higher than the permissible level of the samples which are nearby the dumping yard as the contour lines are assembling around the dumpsite. The concentration of chlorides in all the samples under investigation is 12.4 to $1316 \mathrm{mg} / \mathrm{l}$. It has been observed that concentration of total hardness (TH) of water samples varies from $118 \mathrm{mg} / \mathrm{l}$ to $2070 \mathrm{mg} / \mathrm{l}$. The presence of high concentration of iron and fluoride in the water samples adjacent to dumping yard indicate that it would have contaminated by leachate movement from MSW. The contour plots also reveal that the groundwater was contaminated as per the tests conducted for physical and chemical parameters.
\end{abstract}

Keywords : Groundwater, Municipal Solid Waste, Pollution, Water quality, Waste Disposal.

\section{INTRODUCTION}

In developing countries, the generation of solid waste has become a growing environmental problem in the world everywhere. Rapid Urbanization and economic growth are the most important reasons that lead to generation of solid waste at an increased rate. Inadequate solid waste administration system is the source for pollution of air, soil and water. Particularly improper dumping of solid waste

Revised Manuscript Received on December 30, 2019.

* Correspondence Author

Thayalnayaki D*, Department of Civil Engineering, Periyar Maniammai Institute of Science \& Technology, Vallam, Thanjavur. Email:thayalnayaki@pmu.edu

Jayanthi R, Professor, Department of Civil Engineering, Periyar Maniammai Institute of Science \& Technology, Vallam, Thanjavur. Email:jayanthi@pmu.edu

(C) The Authors. Published by Blue Eyes Intelligence Engineering and Sciences Publication (BEIESP). This is an open access article under the CC BY-NC-ND license (http://creativecommons.org/licenses/by-nc-nd/4.0/) contaminates the surface and groundwater resources. Open dumping are the

most established and basic method for disposal of Municipal solid waste. Now days, they situated wherever open space is accessible, without considering the health and safety aspect. In many areas, the waste is ignited and allowed to burn. In other way, the waste is transferred, leveled and compacted frequently. Open dumping of municipal solid waste in uncontrolled landfills can cause critical effects on the human health and the surrounding environment (Dong et al. 2008). Particularly it informed threat to human health from these landfills site is from the use of groundwater and it has been contaminated by leachate (Jhamnani and Singh 2009).

The municipal waste disposal sites and landfills have a greater possibility of surface/groundwater pollution around the field because; the leachates originate from the organics waste decomposition at the site and finally percolate into the aquifers. Leachate is generally consists of most elements like Calcium, Potassium, magnesium, ammonia and nitrogen, metals like iron, lead, copper, nickel, chromium. The organic compounds such as phenols, acetone, poly aromatic hydrocarbons, benzene, chloroform, toluene, etc. (Freeze and Cherry 1979).

The groundwater level keeps on fluctuating and hence Thanga Gurusany et al 2018; Chavan et al 2014; Lokman Hossain et. al 2014; Parameswari and Karunakaran 2010; Moradeyo Olabisi Odunlami 2012; Sampath Kumar et. Al 2009; Bharat Jhamnani and SK Singh 2009) have conducted pre , post and ongoing examinations and assessed the groundwater contamination due to leachate from landfill sites at various places.

In developing and developed countries, ground water resources are most important for life of people. Awareness of the people about solid waste management is not uniform in developing and developed countries. In spite of Public sector undertaking of the solid waste management, cooperation of the people is not at expected level due to lack of awareness on the issues.

Fresh water is available in the form of ground water and is available in good quality. Ground water unlike surface water will preserve public health, have economic value and responsible for ecological function as stated by Armon and Kitty 1994. As per Babiker et al. 2007, the suitability of ground water for human consumption, industrial, irrigation and for other purposes is always decided based on the physical chemical characteristics. Hence, observing the standard qualities of water is very much vital because safe water is important for human health and the stability of aquatic ecosystems.

The aim of the study is to investigate the level of groundwater contamination due to leachate percolation from Srinivasapuram unlined landfill site of Thanjavur city.

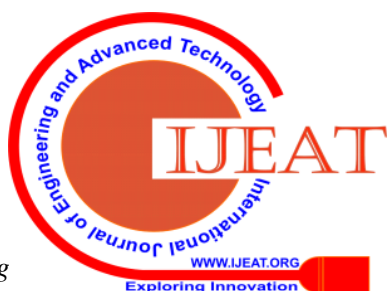


The assessment of groundwater quality in the area is both timely and important which justifies this work. Spatial distribution analysis of ground water quality will be useful so that more attention can be given to highly contaminated area. The environmental degradation also affects the socioeconomic condition of the nearby habitation which is the major problem prevailing around the dumpsite.

\section{STUDY AREA}

In the present study, City of Thanjavur, Tamilnadu was chosen. Thanjavur city lies between $10^{\circ} 09^{\prime} 00^{\prime \prime} \mathrm{N}$ to $11^{\circ} 14^{\prime}$ $00^{\prime} \mathrm{N}$ Latitude, $78^{\circ} 50^{\prime} 00^{\prime} \mathrm{E}$ to $79^{\circ} 33$ '30"E longitude. The branches of Cauvery river, namely, the Grand Anaicut canal, Vadavaaru and Vennaaru rivers flow through the Thanjavur city. It is located in the Cauvery delta, surrounded by Trichy and Cuddalore districts on the North, Thiruvarur and Nagapattinam districts on the East, Palk Strait and Pudukottai district on the South and Pudukottai, Trichy districts on the West. The city has an elevation of $59 \mathrm{~m}$ above mean sea level. The total area of the town is $36.33 \mathrm{~km}^{2}$ and with 14 divisions covering 51 wards. The maximum and minimum temperature of the Thanjavur is about $33.7^{\circ} \mathrm{C}$ and $25.6^{\circ} \mathrm{C}$ respectively. The average annual rainfall is $922.81 \mathrm{~mm}$. The population of the area is 2,22,943 (Census India 2011). The Srinivasapuram dumpsite situated at $10^{\circ} 47^{\prime} 28.29$ ', North and $79^{\circ} 7^{\prime} 31.24^{\prime \prime}$ 'East. The dumping site has an elevation of $78.7 \mathrm{~m}$ above mean sea level. As per records the age of the dump site is around 32 years.

The quantity of solid waste that is currently dumped in the site is approximately $110 \mathrm{MT}$ per day. The open dumping site is about 20 acres in size and the dumping height of the waste is around 3-5 $\mathrm{m}$ above ground level. At the dumping yard the groundwater level is about $24.7 \mathrm{~m}$ below the ground level. The solid waste is dumped without any segregation and compaction. The disposed waste at the landfill has no provision for daily or intermediate covers. At the bottom of the dumping site there is a chance of leachate migration. The dumping yard is freely accessible to all such as rag pickers are regularly utilized and segregated the recyclable materials and also animals including pigs, cattle, buffaloes and dogs searching the food waste. Diseases such as dysentery, cholera and hepatitis are commonly spread in the surrounding areas due to consumption of contaminated groundwater. Map of Thanjavur showing the landfill site under study is shown in Fig. 1

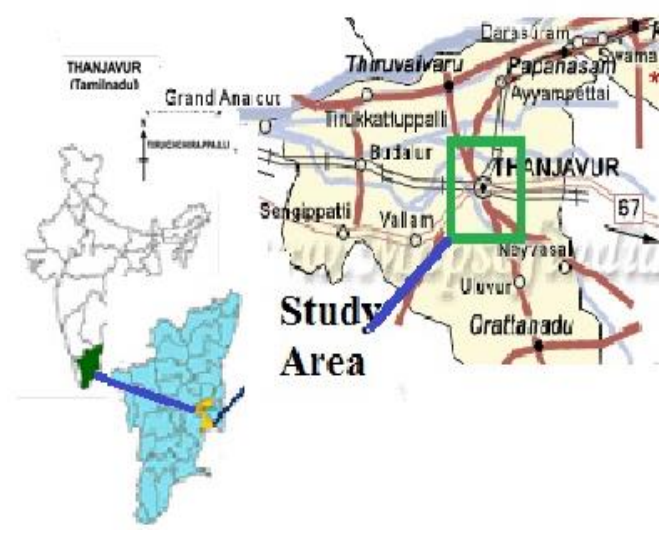

Fig. 1 Study area Map of Thanjavur showing the landfill site@ Srinivasapuram, Thanjavur

\section{MATERIAL AND METHODS}

The Groundwater samples were collected from bore wells and open wells. The groundwater samples are collected in random sampling method with respect to topography, land use patterns and areas adjacent to dumping yard (Kale et al. 2010). Totally 25 numbers of water samples (17 bore wells and 8 open wells) were collected within $2 \mathrm{~km}$ from the yard. The spatial coordinates of the sampling locations were observed using GPS and were shown in Table I.

Table I Details of the sample locations and coordinates

\begin{tabular}{|c|c|c|c|}
\hline $\begin{array}{c}\text { Well } \\
\text { point }\end{array}$ & Place & Latitude & Longitude \\
\hline W1 & Balaganapathy Nagar -1 & $10^{\circ} 47 ' 32.41 " \mathrm{~N}$ & 79॰7' 35.58" E \\
\hline W2 & Anantha Nagar & $10^{\circ} 47^{\prime} 39.81^{\prime \prime} \mathrm{N}$ & 797' 31.74" E \\
\hline W3 & Anantha Nagar & $10^{\circ} 47^{\prime} 39.13^{\prime \prime} \mathrm{N}$ & 79॰7' 30.03" E \\
\hline W4 & Rajarajacholan Nagar-1 & $10^{\circ} 47^{\prime} 17.03^{\prime \prime N}$ & 797' 43.13" E \\
\hline W5 & Tamil Annai nagar-1 & $10^{\circ} 47^{\prime} 33.47^{\prime \prime N}$ & $79^{\circ}$ 7' 7.25" E \\
\hline W6 & Tamil Annai nagar-2 & $10^{\circ} 47^{\prime} 3.35^{\prime \prime} \mathrm{N}$ & $79^{\circ} 8^{\prime} 14.60^{\prime \prime} \mathrm{E}$ \\
\hline W7 & Balaganapathy Nagar -2 & $10^{\circ} 47^{\prime} 19.54 " \mathrm{~N}$ & $79^{\circ} 7{ }^{\prime} 37.74^{\prime \prime} \mathrm{E}$ \\
\hline W8 & Balaganapathy Nagar -3 & $10^{\circ} 47^{\prime} 54.17^{\prime \prime} \mathrm{N}$ & $79^{\circ} 7^{\prime} 29.74^{\prime \prime E}$ \\
\hline W9 & Rajarajacholan Nagar -2 & $10^{\circ} 47^{\prime} 54.17^{\prime \prime} \mathrm{N}$ & $79^{\circ} 77^{\prime} 29.74^{\prime \prime E}$ \\
\hline W10 & M.P.Nagar-1 & $10^{\circ} 47^{\prime} 20.86^{\prime \prime} \mathrm{N}$ & $79^{\circ} 7^{\prime} 37.47^{\prime \prime} \mathrm{E}$ \\
\hline W11 & M.P.Nagar-2 & $10^{\circ} 47^{\prime} 21.76^{\prime \prime} \mathrm{N}$ & $79^{\circ} 7^{\prime} 43.03^{\prime \prime} \mathrm{E}$ \\
\hline W12 & Rajarajacholan Nagar -3 & $10^{\circ} 46^{\prime} 58.126^{\prime} \mathrm{N}$ & $79^{\circ} 7^{\prime} 22.56^{\prime \prime} \mathrm{E}$ \\
\hline W13 & Near saibaba Temple & $10^{\circ} 47^{\prime} 55.99 " \mathrm{~N}$ & 79॰11'30.34"E \\
\hline W14 & P.R.Nagar & $10^{\circ} 47^{\prime} 48.89 " \mathrm{~N}$ & $79^{\circ} 7{ }^{\prime} 38.14^{\prime \prime} \mathrm{E}$ \\
\hline W15 & Kasukadi Street & $10^{\circ} 47^{\prime} 25.22^{\prime \prime} \mathrm{E}$ & $79^{\circ} 8 ' 1.10^{\prime \prime} \mathrm{E}$ \\
\hline W16 & Reddypalayam Road & $10^{\circ} 47^{\prime} 24.41^{\prime \prime} \mathrm{N}$ & $79^{\circ} 7^{\prime} 32.60^{\prime \prime} \mathrm{E}$ \\
\hline W17 & Chekkadi Street-2 & $10^{\circ} 47^{\prime} 24.68^{\prime \prime} \mathrm{N}$ & $79^{\circ} 7^{\prime} 39.10^{\prime \prime} \mathrm{E}$ \\
\hline W18 & Compost Road-2 & $10^{\circ} 47^{\prime} 27.11^{\prime \prime} \mathrm{N}$ & $79^{\circ} 7^{\prime} 26.11^{\prime \prime E}$ \\
\hline W19 & Anandha Nagar - 2 & $10^{\circ} 47^{\prime} 27.11^{\prime \prime} \mathrm{N}$ & $79^{\circ} 7^{\prime} 26.38^{\prime \prime} \mathrm{E}$ \\
\hline W20 & Chekkadi Street-1 & $10^{\circ} 47^{\prime} 30.41^{\prime \prime} \mathrm{N}$ & 79"7'30.24"E \\
\hline W21 & Compost Road-1 & $10^{\circ} 47^{\prime} 33.14^{\prime \prime} \mathrm{N}$ & $79^{\circ} 7^{\prime} 31.04^{\prime \prime} \mathrm{E}$ \\
\hline W22 & Chekkadi Street-3 & $10^{\circ} 47^{\prime} 31.57^{\prime \prime N}$ & $79^{\circ} 7^{\prime} 36.55^{\prime \prime} \mathrm{E}$ \\
\hline W23 & Anandha Nagar- 1 & $10^{\circ} 47^{\prime} 24.75^{\prime \prime} \mathrm{N}$ & $79^{\circ} 7^{\prime} 27.61^{\prime \prime} \mathrm{E}$ \\
\hline W24 & Compost yard & $10^{\circ} 47^{\prime} 26.62^{\prime \prime} \mathrm{N}$ & $79^{\circ} 7^{\prime} 31.04^{\prime \prime} \mathrm{E}$ \\
\hline W25 & Compost Yard & $10^{\circ} 47^{\prime} 31.69^{\prime \prime} \mathrm{N}$ & $79^{\circ} 7^{\prime} 32.46^{\prime \prime} \mathrm{E}$ \\
\hline
\end{tabular}

The ground water samples were collected in 5 lit. polypropylene fresh containers after cleansing with the sample and well-preserved airtight to avoid evaporation, stored at $4^{\circ} \mathrm{C}$ and tested before 2 days in the laboratory. All samples were properly labeled with the date and time of sampling and details of the source. The physicochemical characteristics were chosen for lab test based on their virtual importance in landfill leachates composition and their pollution potential on groundwater resource in particular area (Bagchi 2004). The collected samples were subjected to tests for evaluating $\mathrm{pH}$, Turbidity, Chlorides, Total Hardness (TH), Total dissolved solids (TDS), Fluoride and Iron. $\mathrm{pH}$ and Turbidity was analysed by using digital $\mathrm{pH}$ meter and Nephleo Turbidity meter. Total hardness and chlorides of the groundwater samples were analyzed by titrimetric methods. Every test were completed a number of times till concordant values were arrived. (APHA 1998). Contour map is a typical graphical method to become aware of information from the given set of data representing the spatial variation of any scalar potential. In this study, the scalar potential measured here is the ground water quality. Spatial variations of the physicochemical parameters of the ground water quality in and around dumping yard are to be drawn using contour mapping software such as Surfer 6.0. Based on the data set range the contour interval is chosen. The water quality parameters selected are $\mathrm{pH}$ value, Turbidity, Total dissolved solids (TDS), Total Hardness, Chloride, Fluoride and iron in the groundwater using $\mathrm{mg} / \mathrm{l}$. 


\section{RESULT AND DISCUSSION}

In the present study the collected groundwater samples nearby dumping yard are free from odour and colour. The groundwater is only used for drinking and domestic activities. The acceptable and permissible limit of the water quality parameters for drinking water recommended by World Health Organisation and Bureau of Indian Standards (IS 10500-2012) are shown in the Table. II

Table II Water Quality Standards

\begin{tabular}{|c|c|c|c|}
\hline \multirow[b]{2}{*}{ Parameters } & \multicolumn{2}{|c|}{$\begin{array}{c}\text { BIS standards (IS } \\
\text { 10500:2012) }\end{array}$} & \multirow{2}{*}{$\begin{array}{c}\text { World } \\
\text { Health } \\
\text { Organizatio } \\
\text { n (WHO) } \\
\text { (2002) } \\
\end{array}$} \\
\hline & $\begin{array}{l}\text { Acceptab } \\
\text { le limit }\end{array}$ & $\begin{array}{c}\text { Permissible } \\
\text { limit }\end{array}$ & \\
\hline $\begin{array}{ll}\text { Colour, Hazen } \\
\text { units }\end{array}$ & 5 & 15 & $\begin{array}{c}\text { No } \\
\text { guidelines }\end{array}$ \\
\hline Odour & $\begin{array}{c}\text { Agreeabl } \\
\mathrm{e}\end{array}$ & Agreeable & $\begin{array}{c}\text { No } \\
\text { guidelines }\end{array}$ \\
\hline $\mathrm{pH}$ & $6.5-8.5$ & $\begin{array}{c}\text { No } \\
\text { relaxation }\end{array}$ & $6.5-9.2$ \\
\hline Taste & $\begin{array}{c}\text { Agreeabl } \\
\mathrm{e}\end{array}$ & Agreeable & $\begin{array}{c}\text { No } \\
\text { guidelines }\end{array}$ \\
\hline Turbidity, NTU & 1 & 5 & $\begin{array}{c}\text { No } \\
\text { guidelines }\end{array}$ \\
\hline $\begin{array}{l}\text { Total dissolved } \\
\text { solids, mg/l }\end{array}$ & 500 & 2000 & 250 \\
\hline Chloride, $\underline{\mathrm{mg} / \mathrm{l}}$ & 250 & 1000 & 200 \\
\hline Fluoride mg/l, & 1 & 1.5 & 1.5 \\
\hline Iron, mg/l & 0.3 & $\begin{array}{c}\text { No } \\
\text { relaxation }\end{array}$ & 0.3 \\
\hline $\begin{array}{l}\text { Sulphate }\left(\text { as } \mathrm{SO}_{4} \text { ) }\right. \\
\mathrm{mg} / \mathrm{l}\end{array}$ & 200 & 400 & 50 \\
\hline $\begin{array}{l}\text { Total alkalinity as } \\
\text { calcium carbonate, } \\
\text { mg/l }\end{array}$ & 200 & 600 & 500 \\
\hline $\begin{array}{l}\text { Total hardness (as } \\
\mathrm{CaCO}_{3} \text { ), mg/l }\end{array}$ & 200 & 600 & 300 \\
\hline $\begin{array}{l}\text { Magnesium (as } \\
\text { Mg), mg/l }\end{array}$ & 30 & 100 & 200 \\
\hline $\begin{array}{l}\text { Calcium (as Ca), } \\
\mathrm{mg} / \mathrm{l},\end{array}$ & 75 & 200 & 150 \\
\hline Zinc (as Zn), mg/l, & 5 & 15 & 5 \\
\hline
\end{tabular}

The distribution of pH value, Turbidity, TDS, chlorides, TH, Chlorides, Fluoride, Iron in the groundwater samples are shown in Fig. 2toFig.8The concentration contours are drawn using Surfer 6.0.

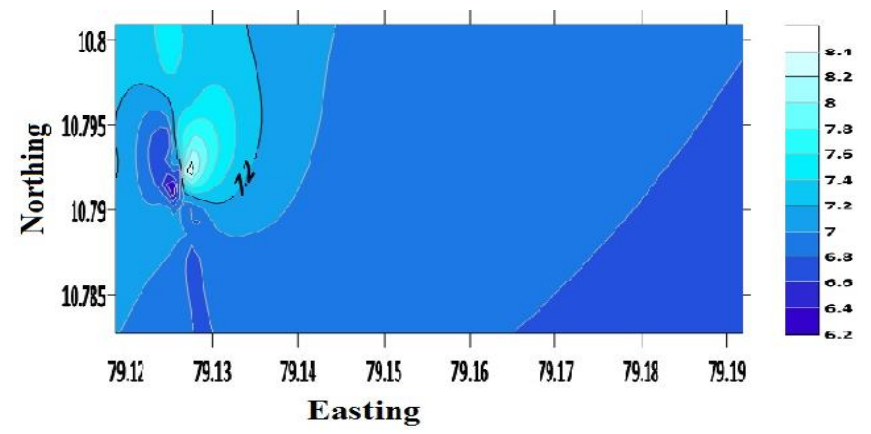

Fig.2 Contour diagram of $\mathrm{pH}$ distribution profile in water Samples

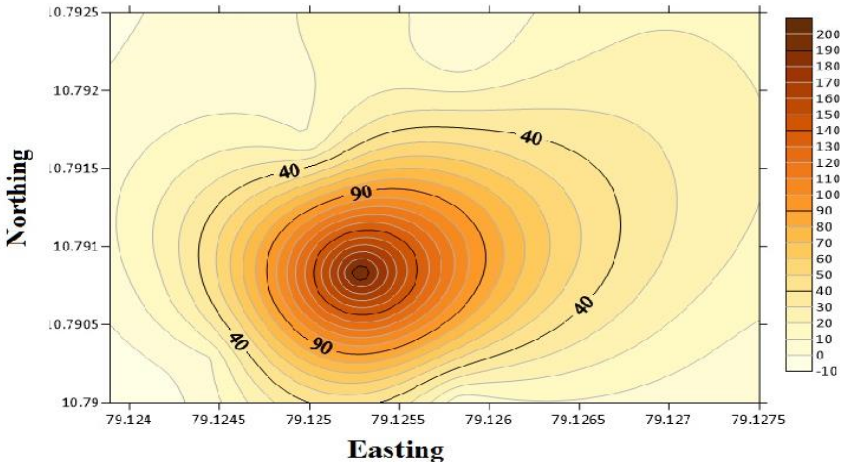

Fig.3 Contour diagram of Turbidity distribution profile in water samples

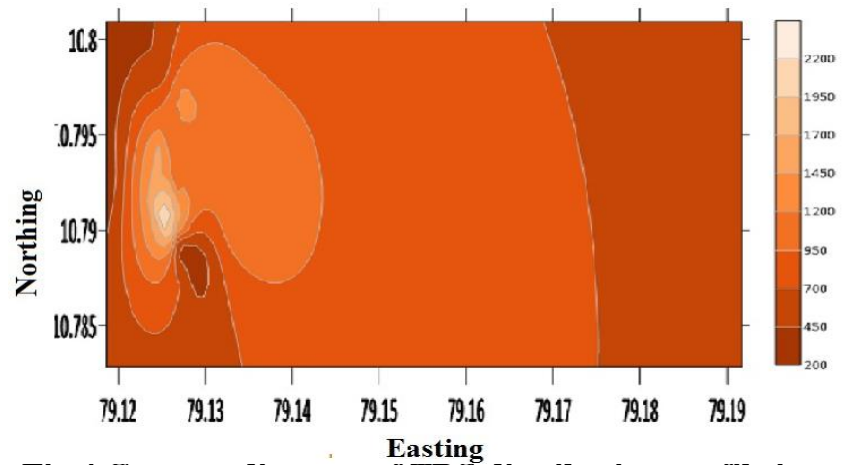

Fig.4 Contour diagram of TDS distribution profile in water samples

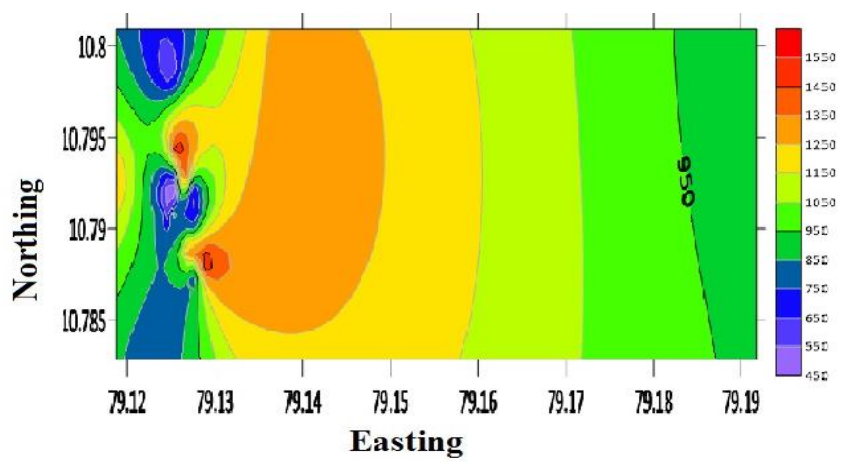

Fig.5 Contour diagram of TH distribution profile in water samples

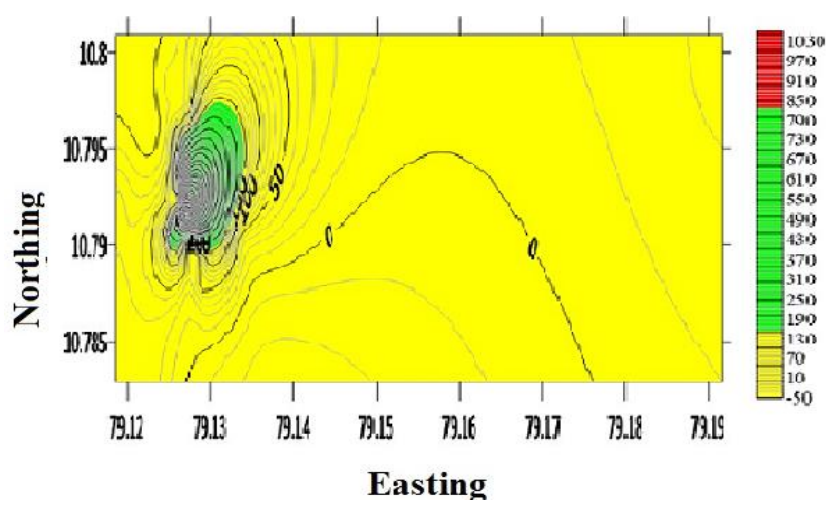

Fig.6 Contour diagram of chlorides distribution profile in water samples 


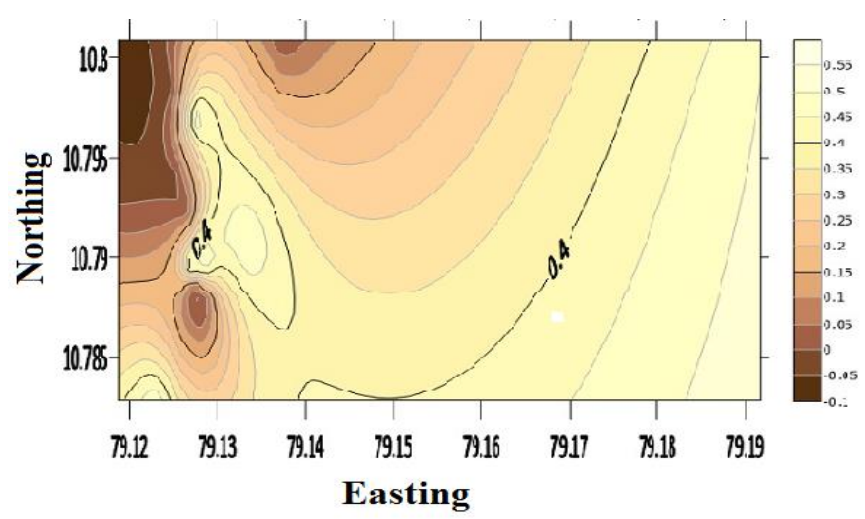

Fig.7 Contour diagram of Fluoride distribution profile in water samples

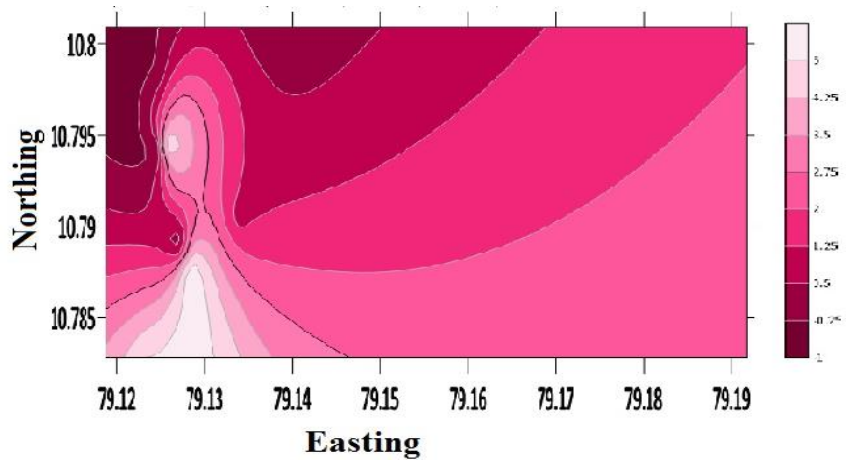

Fig.8 Contour diagram of Iron distribution profile in water samples

During test $\mathrm{pH}$ values of all the samples are found within the allowable range of 6.5-8.5 as specified in Fig.2 as per Bureau of Indian Standards (BIS 2012) and World Health Organization (2002). This value shows that the groundwater of the research study area is mainly of alkaline in nature. Electrical Conductivity is an indicator of inorganic ions dissolved in the groundwater; the high EC in the close area of dumpsite specifies the effect of leachate in groundwater.

As shown in Fig .3 in the study area, the EC value ranges between $0.5 \mathrm{mho} / \mathrm{cm}$ and $5.7 \mathrm{mho} / \mathrm{cm}$. The high value of electrical conductivity is a symptom of contamination of ground water.

Concentrations of Total Dissolved Solids form important characteristics in drinking water and other water quality standards. To determine the suitability of groundwater for any purpose, it is essential to classify the groundwater depending upon their hydro chemical properties based on their TDS values (Catroll 1962; Freeze and Cherry 1979). The TDS values ranges between 200and $3024 \mathrm{mg} / \mathrm{l}$ as shown in Fig.4 . The concentration of TDS of the collected samples nearby the dumping yard are higher than the permissible limit and hence the contour lines resulting in clustering around the dumpsite.

Total Hardness is usually stated as the total concentration of magnesium and calcium in $\mathrm{mg} / \mathrm{l}$ equivalent of Calcium Carbonate. It has been observed from Fig.5 that concentration of total hardness (TH) of water samples varies from $118 \mathrm{mg} / \mathrm{l}$ to 2070mg/l . Total hardness was greater than the acceptable level of $300 \mathrm{mg} / \mathrm{l}$ almost in all locations. This shows that the ground water samples are very hard in nature. The presence of multivalent cation is easily precipitated and make it difficult to remove scum when react with soap. The range of concentration of Iron in all locations under examination is 0.01 to $5 \mathrm{mg} / \mathrm{lit}$. The iron concentration level is all locations except W2 exceed the permissible level as indicated by IS standards.

Chloride concentrations contour lines are also in the same trend with TDS concentration as TDS is having significant correlation with chloride. The concentration of chlorides in all the samples under examination is given in Fig.6 as 12.4 to $1316 \mathrm{mg} / \mathrm{l}$. The values of chlorides in four locations exceeds the permissible limit as per IS 10500-2012. Acceptable level of Chloride concentration is not harmful, but it form corrosion when the concentrations level greater than 250 $\mathrm{mg} / \mathrm{L}$. In spite of that when the concentration is higher than $400 \mathrm{mg} / \mathrm{L}$, it create water as salty taste. An excess of amount chloride in water is an sign of pollution and considered as the groundwater contamination (Loizidou and Kapetanios 1993). The chloride concentration in the ground water may be increased due to leakage of sewage, suspension of rocks surrounding the aquifer and manmade pollution (agricultural activities). Normally the concentration of chloride is greater than the permissible level may cause asthma, renal stones, hypertension and osteoporosis (McCarthy 2004).

Presence of iron shown in Fig.7 and it can lead to change of color of groundwater (Rowe et al. 1995). The fluoride concentration in water is higher than $1.5 \mathrm{mg} / \mathrm{l}$ as given in Fig .8 and it will cause chronic dental fluorosis where the tooth becomes colored from yellow to brown. Due to the continuous consumption of fluoride contaminated water lead to Skeletal fluorosis and it causes weakness and bending of the bones. The results indicated that all the collected sample locations were contaminated due to the migration of leachate. Hence, the water is not potable for drinking purpose. The consumption of the contaminated water may increases the risk of health effects to the people residing in the neighborhood of the dumpsite

\section{CONCLUSION}

Municipal landfills are considered a serious danger to their surrounding environments and a major source of pollution particularly ground water contamination. The water quality examination completed in the selected site shows that quality has been degraded. The concentration of TDS, chloride, Total Hardness, Iron and fluoride is high. The pollutant is not only controlled by the distance of the well from the dumpsite but also to the hydraulic gradient and hydrogeological conditions of the site. From the study it has been perceived that improper practices of solid waste management carried out at the landfill site and the inappropriateness of the leachate collection system and its treatment or recycling exert remarkable impact on the surface and ground water quality. Study has revealed that the groundwater is unacceptable for drinking water practices and construct appropriately engineered sanitary landfill sites to restrict the contamination of ground water. The study emphasized to conduct many awareness programs regarding solid waste disposal, groundwater contamination and proper treatment methods. It is also observed that the following activities have been undertaken for proper management of leachate:

- Construction of embankment surrounding leachate collection ditch and the landfill is in progress thereby during rainy season the surface run off leachate can be reduced.

\section{Published By:}


- Provision of proper liner impermeable clay cover/ HDPE geo textile membrane to reduce the infiltration of the water through the landfill cover.

It is also suggested to provide vegetation cover over the landfill to increase the evapo-transpiration rate and also reduce leachate production.

\section{REFERENCES}

1. Armon R, Kitty (1994) The Health dimension of groundwater contamination. In: Holler (ed) Groundwater contamination and control, Marcel Dekker Inc, New York

2. Babiker SI, Mohamed AA, Mohamed TH (2007) Assessing groundwater quality using GIS. Water Resource Management 21:699-715

3. Bagchi A (2004) Design of landfills and integrated solid waste management. Wiley, New Jersey

4. BIS (Bureau of Indian Standards) 10500 -2012.Indian standard drinking water specification, Second version: 1-11.

5. Chavan, B.L., \& Zambane, N.S. (2014). Ground water quality assessment near municipal solid waste dumping site, Solapur, Maharashtra, India (Vol. 2, pp. 73-78). India: Maharashtra.

6. CPCB, Management of Municipal Solid Waste, Central Pollution Control Board, New Delhi, (2000)

7. Dong S, Liu B, Tang Z (2008) Investigation and modeling of the environment impact of landfill leachate on groundwater quality at Jiaxing Southern China. J Environ Technology Engg. 1(1):23-30

8. Freeze RA, Cherry JA (1979) Ground water. Prentice-Hall, Englewood Cliffs

9. Jhamnani B, Singh SK (2009) Groundwater contamination due to Bhalaswa landfill site in New Delhi. Int J Environ Sci. Eng 1(3):121-125

10. Kale SS, Ajay KK, Kumar Suyash, Pawar NJ (2010) Evaluating pollution potential of leachate from landfill site from the Pune metropolitan city and its impact on shallow basaltic aquifers.

11. Kanmani, S., \&Gandhimathi, R. (2013). Assessment of heavy metal contamination in soil due to leachate migration from an open dumping site. Applied Water Science, 3 (1), 193-205.

12. Loizidou M, Kapetanios EG (1993) Effect of leachate from landfills on groundwater quality. Sci Total Environ 128:69-81

13. Lokman Hossain et.al, (2014). Impact of Landfill Leachate on Surface and Groundwater Quality. Journal of Environmental Science and Technology 7(6): 337-346, ISSN 1994-7887

14. McCarthy MF (2004) Should we restrict chloride rather than sodium? Med Hypotheses 63:138-148

15. Parameswari. K \&Karunakaran K (2010). Ground water issues and community Awareness in Perungudi Dumpsite, Chennai, India. Journal of Environmental Research and Development Vol. 5 No. 2, 404-412

16. Rowe RK, Quigley RQ, Booker JR (1995) Clay barrier systems for waste disposal facilities. E and FN Spon, London

17. Sampath Kumar et. al, (2011). Environmental impact of leachate characteristics on water quality, Environ Monit Assess (2011) 178:499-505, DOI 10.1007/s10661-010-1708-9

18. Thanga Gurusamyet. al., (2018). Spatial distribution analysis and mapping of ground water quality across Chennai. International Journal of Civil Engineering and Technology (IJCIET) Volume 9, Issue 4, April 2018, pp. 620-630, Article ID: IJCIET 0904070

19. World Health Organization. (2002). Guidelines for drinking water quality (2nd ed., Vols. 13). Geneva: World Health Organization

\section{AUTHORS PROFILE}

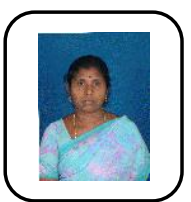

Thayalnayaki D, Research Scholar, Environmental Engineering, Department of Civil Engineering, Periyar Maniammai Institute of Science and Technology, Thanjavur. She published 7 international journals and 1 National journals. She is a life member in Indian Concrete Institute and International Association of Engineers. she has more than a decade experience in teaching field. Email : thayalnayaki@pmu.edu

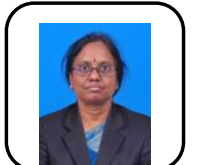

Dr. Jayanthi R, Professor, Department of Civil Engg. Periyar Maniammai Institute of Science and Technology, Vallam, Thanjavur, Tamil Nadu. She obtained her Doctorate in the field of Geo Environmental Engg., National Institute of Technology, Trichy and M.E.Geotechnical Engineering from Annamalai University, Chidambaram. She completed B.E. Civil Engineering from REC, Triuchirappalli. She has interested in the research areas of Geotechnical Engineering, Ground Water Quality Modeling. She published more than 10 research paper in reputed international and national journals 